\title{
Predictive value of islet cell and insulin autoantibodies for Type 1 (insulin-dependent) diabetes mellitus in a population-based study of newly-diagnosed diabetic and matched control children
}

\author{
M.Landin-Olsson ${ }^{1}$, J.P. Palmer ${ }^{5}$, Å. Lernmark ${ }^{5}$, L.Blom ${ }^{3}$, G.Sundkvist ${ }^{1}$, L.Nyström ${ }^{2}$ and G.Dahlquist ${ }^{4}$ \\ ${ }^{1}$ Department of Medicine, University of Lund, Lund, and Malmö General Hospital, Malmö, ${ }^{2}$ Department of Paediatrics, \\ Karolinska Institute, Sachs' Children's Hospital, Stockholm, ${ }^{3}$ Departments of Paediatrics, ${ }^{4}$ Epidemiology and Health Care Research, \\ University of Umeå, Umeå, Sweden, and ${ }^{5}$ Department of Medicine, University of Washington, Seattle, Washington, USA
}

\begin{abstract}
Summary. Most studies evaluating immune markers for prediction of Type 1 (insulin-dependent) diabetes mellitus have focused on first degree relatives, although only $10 \%$ of newlydiagnosed patients have an affected first degree relative. The Swedish Childhood Diabetes Register identifies $99 \%$ of all diabetic children at diagnosis. In this population-based study, islet cell antibodies and insulin autoantibodies in 0-14-yearold Swedish consecutively-diagnosed patients and control subjects were analysed to define their sensitivity and specificity. Over 16 months (1986-1987), 515 Swedish children developed diabetes. Plasma samples were obtained from 494 (96\%) patients, and 420 matched control children. Among patients, the frequency of islet cell antibodies was $84 \%$ ( 415 of 494 ), insulin autoantibodies $43 \%$ (145 of 334 ); $40 \%$ (135 of 334 ) were positive for both and $88 \%$ (294 of 334) were positive
\end{abstract}

for one or both. Among control children, $3 \%$ (14 of 420) had islet cell antibodies, $1 \%$ ( 4 of 390) insulin autoantibodies, and $4 \%$ ( 16 of 390 ) had either autoantibody marker. The predictive value of finding a patient with the disease was only $7 \%$ since $4 \%$ of the control children were antibody-positive and the cumulative incidence rate up to 15 years of age is $0.38 \%$. None of the autoantibody-positive $(n=21)$ or negative control children developed diabetes during 3 to 5 years of follow-up. Longitudinal investigations of islet cell or insulinautoantibody-positive healthy children are necessary to accurately determine the conversion rate from marker positivity to disease onset.

Key words: Autoimmunity, disease prediction, sensitivity, specificity, predictive value.
Most studies on the role of autoimmune markers in the pathogenesis of Type 1 (insulin-dependent) diabetes mellitus have focused on first degree relatives. Although the risk for Type 1 diabetes is increased among relatives, and many of them may have a reduced acute insulin response to glucose $[1,2]$, subclinical Beta-cell dysfunction which does not progress to clinical Type 1 diabetes appears to be common [2, 3]. Islet cell (cytoplasmic) antibodies (ICA) $[4,5]$ and insulin autoantibodies (IAA) [6] are often detected both before and at the time of clinical onset [7]. The ICA [5] and IAA [8] assays have recently been standardized to allow levels to be expressed in common units and valid comparisons can now be made between laboratories screening for diabetes. A possible relationship between ICA or IAA and loss of Beta-cell function has been demonstrated both in newly-diagnosed patients $[9,10]$ and in selected first degree relatives of Type 1 diabetic patients [11-13]. Recent prospective studies carried out over $5-11$ years on more than 6000 first degree relatives $[2,14$ 16] demonstrated a higher frequency of ICA (3-10\%) than of Type 1 diabetes $(0.5-2 \%)$, and suggest that ICA may occur transiently. To avoid ascertainment and re- cruitment bias, patient registries [17-19] and populationbased studies are increasingly important in defining markers for Type 1 diabetes in children who are not relatives to Type 1 diabetic patients.

In the present study, we have determined ICA and IAA levels in consecutive newly-diagnosed Type 1 diabetic children and compared the prevalence and levels with those found in population-based control children to define sensitivity, specificity and predictive value of these markers alone or in combination for Type 1 diabetes. In addition to a population-based design, this study represents the largest number of recent-onset diabetic children ever tested for both ICA and IAA. We have also followedup a similar number of healthy children for up to 5 years to determine if any of them have developed Type 1 diabetes.

\section{Subjects, materials and methods}

All 0-14-year-old children who develop Type 1 diabetes in Sweden are admitted to one of the country's 44 paediatric departments. Newly-diagnosed patients are reported to the Swedish Childhood Diabetes Register at a $99 \%$ level of ascertainment [17, 20-22]. The 


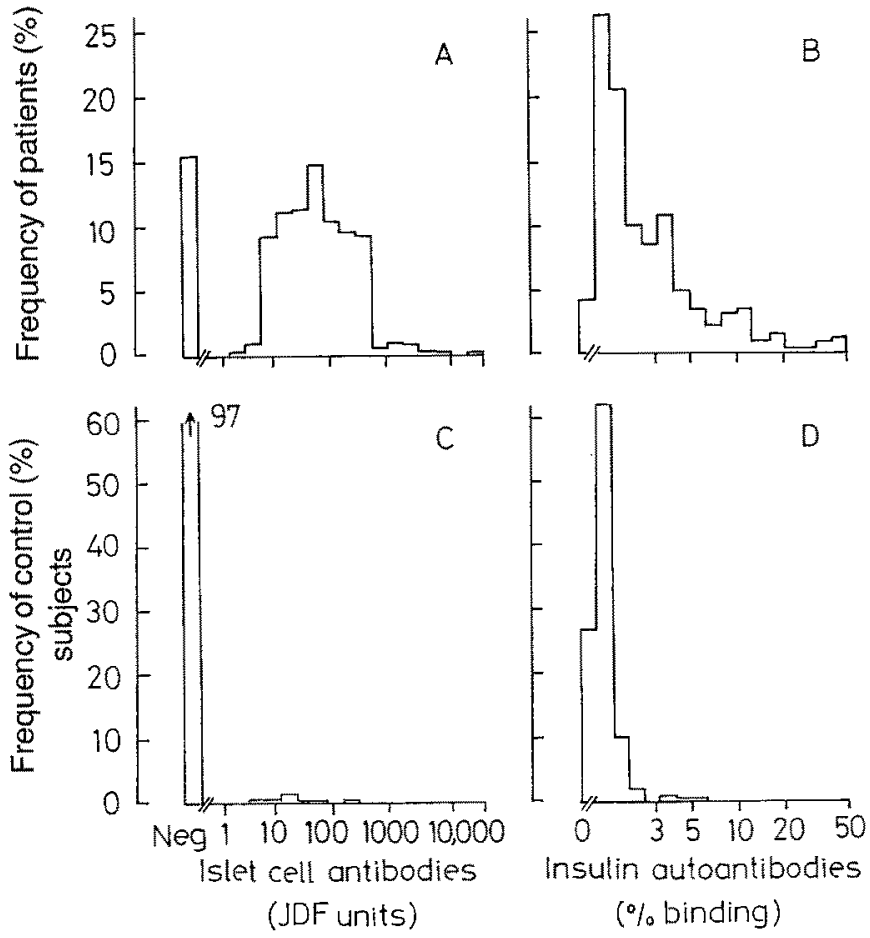

Fig.1A-D. Frequency of newly-diagnosed 0-14-year-old diabetic patients ( $\mathbf{A}$ and $\mathbf{B}$ ), diagnosed consecutively during a 16-month period, and of age, gender and geographically matched control children (C and $\mathbf{D}$ ) is shown in relation to levels of islet cell antibodies (ICA) in Juvenile Diabetes Foundation (JDF) units ( $A$ and $\mathbf{C}$ ) and of insulin autoantibodies expressed as the percent binding of insulin (B and D)

present paper reports the second study of patients and control children, performed between 1 September 1986-31 December 1987. During these 16 months blood samples were obtained from 494 $(96 \%)$ of 515 consecutively-registered patients. The median age of the patients was 9 years, with a range of $1-14$ years. The male to female ratio was $1.08(256: 238)$. The date of diagnosis was defined as the day when the first insulin injection was given. In 355 of 494 patients (72\%) the blood sample was obtained either before or within 5 days after the initiation of insulin therapy and plasma for IAA was available from 334 of 355 of these patients. IAA were not determined on patients treated for 5 days or longer $(n=139)$ to exclude the possibility of detecting antibodies to exogenous insulin. We also tested whether the 139 patients treated with insulin for 5 days or longer introduced a sampling error, but the frequency and levels of ICA, age, gender, geographical and seasonal variation in this group did not differ from the 334 patients who were included in the analysis of IAA.

The control group $(n=423)$ was recruited from two sources. For ethical reasons, blood samples from control children below 7 years of age ( $n=52$, or $12 \%$ of the control subjects) were obtained from children who had been subjected to venepuncture at a paediatric department for reasons other than diabetes or other endocrine or infectious diseases. The second group of control children ( $n=371$, or $88 \%$ of the control subjects) were $7-14$-year-old children selected from the general population as described in detail $[17,23]$ using the civic registration number of the Swedish Population Register to identify a control child born the same day, of the same gender and in the same county. For each of the 3597-14-year-old patients, two control children $(n=718)$ were invited to participate in the study of whom $371(52 \%)$ volunteered. The entire control group comprised 423 children aged $1-15$-years, median age 11 years and a male to female ratio of 1.05 ( 217 of 206 ). It took a median of 6 weeks to receive the blood sample from the control children after the registration of a Type 1 diabetic patient. The control children and their families were informed that the purpose of the study was a health survey without specific mention of diabetes to avoid a selection bias. For ethical reasons, blood was drawn only once from the control children and they have not been contacted for additional tests. During 3 to 5 years of follow-up, the possible development of Type 1 diabetes among control children was monitored continuously through the Swedish Childhood Diabetes Register and the Swedish Diabetes Register for Young Adults. At the first check, three control children ( 3 of 423) were determined as having already been registered as Type 1 diabetic patients in 1983,1984 and 1987, respectively. These three individuals were therefore excluded as control children but their data on ICA and IAA are included to illustrate the ability of these markers to identify children who are already diabetic in the background population of $0-14$-year-olds. When remaining control children were found to be positive for ICA or IAA or both, the paediatric departments in their region were contacted to determine whether Type 1 diabetes had been previously diagnosed.

Informed consent was obtained from all parents and children. The study was approved by the Swedish Data Inspection Board and by the Ethical Committee at the Karolinska Institute, Stockholm, Sweden.

\section{Islet cell and insulin autoantibodies}

Venepuncture was performed to collect $10 \mathrm{ml}$ EDTA blood samples which were sent from the local hospital, or for control children, from community health care clinics to our laboratory in Malmö (Sweden) where the samples were centrifuged, plasma aliquoted and stored at $-80^{\circ} \mathrm{C}$ until further analysis.

ICA were analysed in Malmö in an indirect two-colour immunofluorescence assay using frozen human pancreas of blood group 0 as described in detail [24-26]. Only one pancreas was used throughout the study. Coded slides were evaluated by at least two independent observers. Each assay included internal negative and positive standards in different dilutions. The samples were titrated in $1: 2,1: 4$, $1: 8$, etc., dilutions, and the end point titre was defined as the highest titre of detectable ICA. The levels are expressed in Juvenile Diabetes Foundation (JDF) units by constructing a linear regression line between multiple end point titres of different dilutions [26] from the international reference serum [5]. The SD of the internal positive standard sample showed a variation of 1.0 titration steps, corresponding to a coefficient of variation of $15 \%$. The Malmö ICA laboratory participates in the JDF-sponsored international diabetes workshops and proficiency testing programs. The lower detection limit for our assay is 1 JDF unit.

IAA were measured in Seattle (Washington, USA) using a radiobinding assay as previously described $[6,27]$ and displacement with cold insulin as stipulated by the international workshop on standardization of IAA [8]. Since this assay does not distinguish between insulin antibodies formed in response to exogenous insulin administration and IAA, only the 334 patients who had been treated with insulin for 5 days or less were evaluated. The cut-off level between positive and negative values was $2.3 \%$, defined as the 99 th percentile of the percent binding among the 420 non-diabetic control children.

\section{Statistical analysis}

Values are given as median, range and quartile deviation if not normally distributed, and mean, range and SD if normally distributed. Differences in frequencies and levels of autoantibodies were tested with the chi square and the Mann-Whitney U-test, respectively. The Spearman rank correlation analysis $\left(r_{s}\right)$ was used to test correlations between levels of antibodies and age. Two-tailed probability $(p)$ value of 0.05 was considered to indicate statistical significance. Predictive values were calculated from the formula:

predictive value $=\frac{\mathrm{P} \times \alpha}{\mathrm{P} \times \alpha+(1-\mathrm{P}) \times(1-\beta)}$

where $P$ is prevalence, in Sweden determined to be $0.15 \%$ in $0-14-$ year-olds [20], $\alpha$ is sensitivity (positivity in disease) and $\beta$ is specificity (negativity in health). 

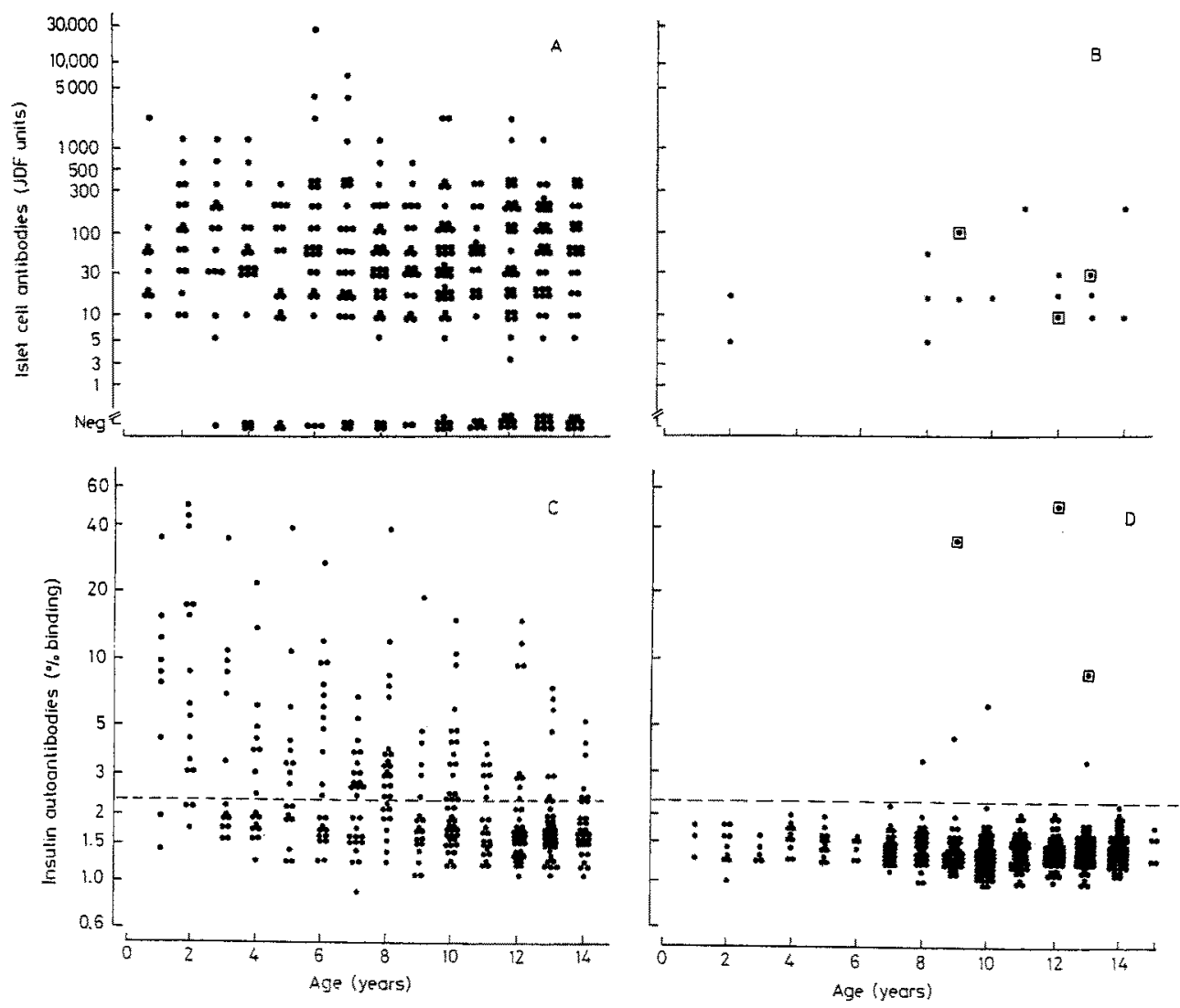

Fig. 2A-D. Levels of islet cell cytoplasmic and insulin autoantibodies in relation to age in newly-diagnosed Type 1 (insulin-dependent) diabetic children and in gender, age, and geographically matched control children. The dashed line indicates the cut-off level for insulin autoantibodies (IAA) (C and $\mathbf{D})$ based on the levels in the control children (D). Three children already registered in the Swedish Childhood Diabetes Register are indicated ( $\bullet$ ) (JDF units) Juvenile Diabetes Foundation units

\section{Results}

The prevalence of ICA (Fig. 1) was 415 of 494, or $84 \%$ among the newly-diagnosed Type 1 diabetic children (Fig. 1,A). The range of ICA was 3-26,500 JDF units, and the median level was 57 JDF units among ICA positive Type 1 patients. The frequency of ICA positive control subjects was 14 of 420 , or $3 \%$ (Fig. 1,C). The levels of ICA ranged between 5-200 JDF units, and the median level was $17 \mathrm{JDF}$ units in ICA positive control children. The median level of ICA in the patients (57 JDF units) was not significantly different from the control subjects (17 JDF units). The levels of ICA in the three control children found to be already registered as Type 1 diabetic patients (Fig.2) were 9,26 and 110 JDF units, respectively.

IAA were analysed in 334 newly-diagnosed Type 1 diabetic children who had received insulin for 5 days or less. IA A have previously not been analysed in a childhood population and the control children were used to establish a normal range (Fig. 2D). LAA binding in the newly-diagnosed Type 1 diabetic patients ranged from $0.9-50.3 \%$; the median percent binding was $20 \%$ (Fig. 2C). The control subjects defined the cut-off limit for the 99 th percentile as greater than $2.3 \%$, hence $1 \%$ ( 4 of 390 ) were IAA positive, with a range $3.6-6.2 \%$ binding. Using this cut-off level, IAA were present in $43 \%$ of the patients. The three control children already reported to the Diabetes Register (Fig.2D), had been treated with insulin for 7 months, 3 and 4 years, respectively. Accordingly, their high level of percent binding is most likely explained by the presence of insulin antibodies, and not IAA.
We then analysed the extent to which ICA were related to IAA and to other epidemiological features of Type 1 diabetes such as age, gender, geographical location and seasonal variation. In patients, ICA (Fig. 2A) and IAA (Fig. 2C) showed a weak but significant negative correlation with age $\left(r_{\mathrm{s}}=-0.1, p<0.02\right.$ and $r_{\mathrm{s}}=-0.4, p<0.001$, respectively). ICA levels correlated to IAA $\left(r_{\mathrm{s}}=0.3\right.$; $p<0.001$ ) (Fig. 3 A). There was no effect of gender, geographical location or season of diagnosis on the frequency or levels of ICA or IAA (data not shown).

The frequency of patients positive for ICA or IAA or both was $88 \%$ ( 294 of 334 ), with $40 \%$ (135 of 334) positive for both. In 390 control children analysed for both ICA and IAA, 4\% (16 of 390) were positive for ICA or IAA; no non-diabetic control child was positive for both autoantibodies (Fig. 3).

The sensitivity, specificity and predictive values for ICA and IAA alone or in combination are summarized in Table 1. It should be noted that these predictive values are an indication of the ability of the test to find a patient with undiagnosed Type 1 diabetes in the general population. The positive predictive value for Type 1 diabetes following a positive screen needs to be determined in longitudinal studies. ICA and IAA alone had high specificity (97$99 \%)$, but, the low prevalence $(0.15 \%)$ or cumulative incidence rate $(0.38 \%)$ of Type 1 diabetes in the general Swedish childhood population $[20,22]$ resulted in predictive values varying between 4 and $14 \%$. Positivity of ICA IAA or both increased the sensitivity, but the predictive value remained low ( $3 \%$ and $7 \%$ respectively). Positivity for both autoantibodies was not found in any of the con- 


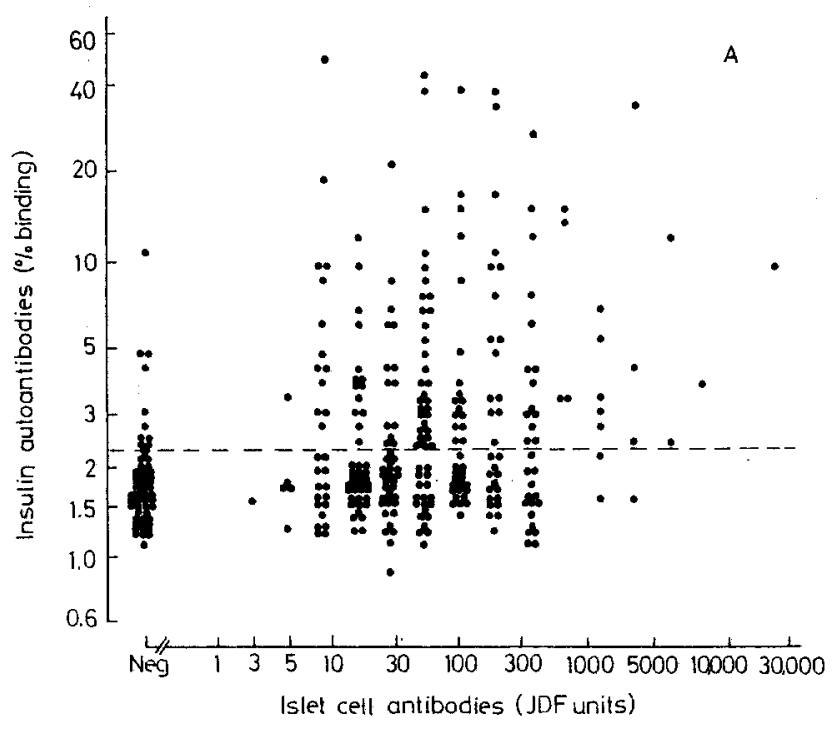

Fig. 3A,B. Islet cell (cytoplasmic) antibodies (ICA) in Juvenile Diabetes Foundation (JDF) units in relation to levels of insulin autoantibodies (IAA) expressed as percent insulin binding in consecutive newly-diagnosed (insulin treatment for 5 days or less) Type 1 (insulin-dependent) diabetic children (A) and in gender, age and

trol children, but fewer than half of all diabetic patients $(40 \%)$ would be detected using this criterion (Table 1$)$. The Swedish Diabetes Register has been monitored during a 3 to 5 year follow-up period for the possible registration of a diagnosis of Type 1 diabetes for the 420 control children who participated in this case-control study. As of March 1992, none of the 18 antibody-positive, nor any of the negative control children have been registered. It is projected that 14,815 children will have to be followed-up for 5 years to detect 20 diabetic patients (Table 2 ).

\section{Discussion}

A variety of antibodies against islet cells $[4,6,9,28-32]$ are used as markers for autoimmune destruction of the pancreatic Beta cells, but these may not be pathognomonic since they sometimes occur transiently without progression to Type 1 diabetes [23]. Prospective family studies initiated more than 10 years ago, however, have also revealed that ICA might be present long before the clinical onset of the disease $[13,33]$. These initial studies of ICA were confirmed and extended to IAA [13, 34-36] but usually in highly selected first degree relatives. The conversion rate from marker positivity to clinical Type 1 diabetes is variable for the different autoantibodies [2, 3, 14]. First-degree relatives do not seem to reflect the majority of the 0-14-year-old group who develop diabetes.

A fundamental step in population-based investigations of Type 1 diabetes markers is to determine their sensitivity, specificity and predictive value [23]. The ICA levels in our previous [23] and present studies were remarkably similar. Together, the two studies report a total of 886 newly-diagnosed 0-14-year-old Type 1 diabetic patients. Nevertheless, some children develop Type 1 diabetes without being positive for either IAA or ICA; in this in-

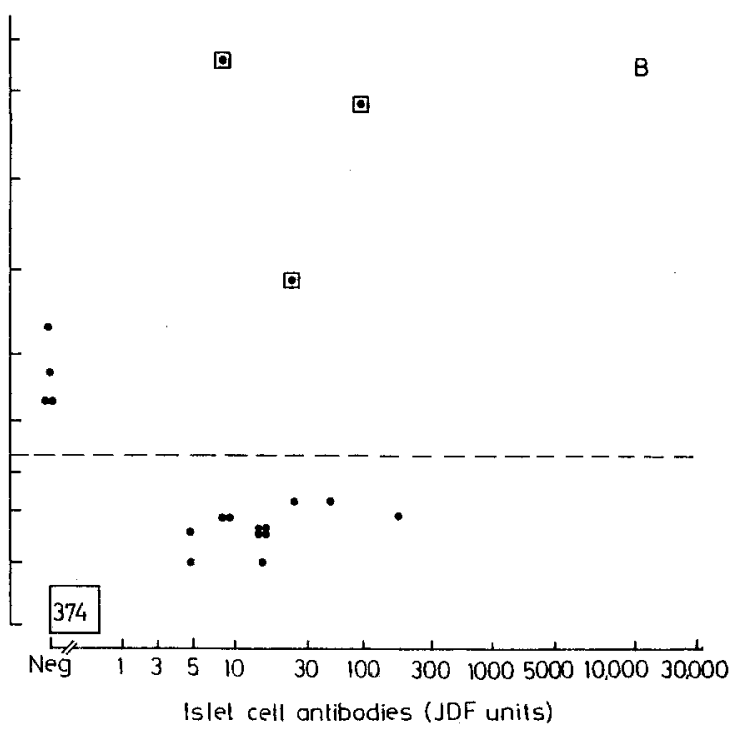

geographically matched control children (B). Three children ( $\square$ ) positive for both ICA and IAA were already registered in the Swedish Childhood Diabetes Register diagnosed with Type 1 diabetes, and were therefore excluded as control subjects

vestigation we found that $40(12 \%)$ of the new patients did not have either marker. All of these 40 children have remained on insulin therapy. It is possible that some patients might have had ICA levels below our detection limit of 1 JDF unit or that they became negative before onset.

The selection of the control group is the most critical step in accurately determining specificity for ICA or IAA or both, and is a serious weakness in many published studies. The Swedish Population Register made it possible for us to select two control children of the same gender, born the same day and living in the same county as the patient. Furthermore, Type 1 diabetes was not specifically mentioned in the recruitment of control children, which reduced the risk for bias towards relatives of diabetic patients. Three children were identified with Type 1 diabetes by comparing the civic registration numbers of all control children against the Swedish Childhood Diabetes Register, illustrating the utility of the Register.

The frequency of ICA among the control children was $3 \%$, equal to our previous study [23]. Since the prevalence of Type 1 diabetes among 0-14-year-olds in Sweden is $0.15 \%$ [20], it is a provocative finding that the ICA frequency exceeds the disease prevalence by a factor of 20 . Prior to the standardization of the ICA assay, the frequency of ICA among control subjects was generally reported as $0.1-1 \%$. After the introduction of ICA standardization and the JDF standard serum, frequencies of $4 \%$ in 1218 Finnish school children [37], 2.2\% in 540 healthy children from the United Kingdom and blood donors [15], and $1.7 \%$ in 7740 French schoolchildren [38] were reported, supporting the hypothesis that ICA in the background population exceeds the prevalence of the disease.

The ICA levels in the 14 control children positive in this study did not differ from the median ICA level of the Type 1 diabetic patients (17 compared to 57 JDF units, 
Table 1. Sensitivity, specificity and positive predictive value of islet cell antibodies (ICA) and insulin autoantibodies (IAA) for Type 1 (insulin-dependent) diabetes mellitus in the 0-14-year age group

\begin{tabular}{lllll}
\hline & ICA & IAA & $\begin{array}{l}\text { ICA or } \\
\text { IAA }\end{array}$ & $\begin{array}{l}\text { Both ICA } \\
\text { and IAA }\end{array}$ \\
\hline Sensitivity (\%) & 84 & 43 & 88 & 40 \\
$95 \%$ CI & $81-87$ & $38-48$ & $85-92$ & $35-45$ \\
Specificity (\%) & 97 & 99 & 96 & 100 \\
$95 \%$ CI & $95-99$ & $98-100$ & $94-98$ & NA
\end{tabular}

Predictive value $(\%)$ based on:

$\begin{array}{lllll}\text { prevalence rate } & 4 & 6 & 3 & 100\end{array}$

The prevalence rate of Type 1 diabetes in the Swedish childhood population is $0.15 \%$ [20]. ICA were determined in 494 patients and 420 control children. IAA, ICA or IAA or both, as well as ICA and IAA were determined in 334 patients and 390 control children. CI, Confidence interval; NA, not applicable

Table 2. Projection of the number of Swedish children to be tested for Type 1 (insulin-dependent) diabetes in a follow-up study

\begin{tabular}{lcc}
\hline $\begin{array}{l}\text { No. of children to } \\
\text { be followed-up }\end{array}$ & $\begin{array}{l}\text { No. of newly-diag- } \\
\text { nosed diabetic children } \\
\text { expected each year }\end{array}$ & $\begin{array}{l}\text { No. of diabetic } \\
\text { children expected at } \\
\text { the 5-year follow-up }\end{array}$ \\
\hline 14,815 & 4 & 20 \\
18,519 & 5 & 25 \\
37,037 & 10 & 50 \\
74,074 & 20 & 100 \\
100,000 & 27 & 135
\end{tabular}

The above estimates are based on an annual incidence rate of 27 per $100,0000-14.99$ year olds

NS). It has been concluded from family studies [14, 15] that ICA of 20 or less JDF units is rarely associated with progression to Type 1 diabetes. This cut-off limit for ICA would result in a sensitivity of $79 \%$, specificity would be $98 \%$ and predictive value $5 \%$, hence, our result would not be changed.

Taking our two studies together, beginning in September 1985 through December 1987, we have studied a total of 741 healthy Swedish children. The longest follow-up is 6 years in these children. In the first year, two out of nine ICA-positive children developed Type 1 diabetes [23]. So far, none of the other ICA $(n=21)$ or IAA $(n=4)$ positive nor any negative control children have been registered as Type 1 diabetic patients. None of the controls was positive for both ICA and IAA in the present study. Therefore, if we had found one control subject positive for both, 1 of 390 or $0.3 \%$, the specificity would be $99.7 \%$ and the positive predictive value would decrease from $100 \%$ (Table 1) to $17 \%$. These calculations demonstrate that a large number of healthy children need to be tested (Table 2) and followed longitudinally to accurately estimate the positive predictive value for Type 1 diabetes. If the entry criterion for intervention trials were single antibody positivity, our study shows that the frequency of false positives would be too high to make such trials ethical [39]. Our study suggests that future studies should measure both ICA and IAA and use a Beta-cell function test $[2,3]$ to refine the ability to predict and thus prevent Type 1 diabetes.
Acknowledgements. Ms. B.Persson, L. Hallner, S. Blaylock, R. Park, J. Watters and Mr. D. Stenger are thanked for skillful assistance and Drs. D. McCulloch and N. Breslow for helpful comments. This work was supported by grants from the Swedish Medical Research Council $(07507,07531)$, the National Institutes of Health (DK 26190, DK 33873, DK 02456, DK 17047), the Juvenile Diabetes Foundation International, the Swedish Diabetes Association, the Malmö Diabetes Association, the Lundström Foundation, the Swedish Insurance Companies Foundation, and the Malmö General Hospital Foundation. M.L.-O. was supported by a fellowship from the Juvenile Diabetes Foundation International.

Members of the Swedish Childhood Diabetes Study from all Departments of Paediatrics in Sweden: M. Aili, Halmstad;H. Bäckman, Gävle; E.Carlsson, Kalmar; H.Edenwall, Karlskrona; P.O.Elfstrand, Skövde; G.Forsander, Falun, B.W.Granström; Gällivare, I. Gustavsson, Skellefteå; L.-E. Gustavsson, Östersund, A. Hallberg, Landskrona; R.Hanås, Uddevalla; L.Hellenberg, Nyköping; H.Hellgren, Lidköping; E.Holmberg, Umeå, H.Hörnell, Hudiksvall; C. Johansson, Jönköping; G. Jonsell, Karlstad; C. Jönsson, Sollefteå; K.Kockum, Ystad; U.Lindberg, Växjö; B.Lindblad, Mölndal; A.Lindh, Borås; J. Ludvigsson, Linköping; V.Mazreliez, Visby; U.Myrdal, Västerås; J.Neiderud, Helsingborg; K.-O.Nilsson, Malmö; P.G.Petzén, Västervik; G.Samuelsson, Vänersborg; K. Segnestam, Eskilstuna; S. Sjöblad, Lund; S.Sjögren, Örnsköldsvik; L.Skogsberg, Boden; T.Smith, Kristianstad, L.Strömberg, Norrköping; U.Ståhle, Ängelholm; J.Tenstam, Sundsvall; B. Thalme, Huddinge; K. Tullus; Danderyd; T. Tuvemo, Uppsala; M. Wallensteen, Stockholm; O. Westphal, Göteborg; and J.Åman, Örebro.

\section{References}

1. Srikanta S, Ganda OP, Eisenbarth GS, Soeldner JS (1983) Islet cell antibodies and beta-cell function in monozygotic triplets and twins initially discordant for type I diabetes mellitus. N Engl J Med 308: 321-325

2. McCulloch DK, Klaff LJ, Kahn SE et al. (1990) Nonprogression of subclinical $\beta$-cell dysfunction among first degree relatives of IDDM patients: 5-yr follow-up of the Seattle family study. Diabetes 39: 549-556

3. Bärmeier H, McCulloch DK, Neifing JL et al. (1991) Risk for developing type 1 (insulin-dependent) diabetes mellitus and the presence of islet 64K antibodies. Diabetologia 34: 727-733

4. Bottazzo GF, Florin-Christensen A, Doniach D (1974) Islet cell antibodies in diabetes mellitus with autoimmune polyendocrine deficiencies. Lancet II 1279-1283

5. Bonifacio E, Lernmark Å, Dawkins RL (1988) Serum exchange and use of dilutions have improved precision of measurement of islet cell antibodies. J Immunol Methods 106: 83-88

6. Palmer JP, Asplin CM, Clemons P et al. (1983) Insulin antibodies in insulin-dependent diabetics before insulin treatment. Science 222: 1337-1339

7. Palmer JP, Lernmark $\AA$ (1990) Pathophysiology of type 1 (insulin-dependent) diabetes. In: Rifkin H, Porte D (eds) Ellenberg and Rifkin's diabetes mellitus; theory and practice $4^{\text {th }}$ edn, Elsevier New York. pp 414-435

8. Kuglin B, Kolb H, Greenbaum C, Maclaren NK, Lernmark A, Palmer JP (1990) The fourth international workshop on the standardisation of insulin autoantibody measurement. Diabetologia 33: 638-639

9. Marner B, Agner T, Binder C et al. (1985) Increased reduction in fasting C-peptide is associated with islet cell antibodies in type 1 (insulin-dependent) diabetic patients: Diabetologia 28: 875-880.

10. Wallensteen M, Dahlquist G, Persson B et al. (1988) Factors influencing the magnitude, duration, and rate of fall of $B$-cell function in type 1 (insulin-dependent) diabetic children followed for two years from their clinical diagnosis. Diabetologia 31: 664-669

11. Srikanta S, Ganda OP, Rabizadeh A, Soeldner JS, Eisenbarth GS (1985) First-degree relatives of patients with type 1 diabetes mel- 
litus: islet-cell antibodies and abnormal insulin secretion. N Engl JMed 313: 462-464

12. Vardi P, Ziegler AG, Mathews JH (1988) Concentration of insulin autoantibodies at onset of type I diabetes: inverse loglinear correlation with age. Diabetes 9: 736-739

13. Ginsberg-Fellner F, Witt ME, Franklin BH et al. (1985) Triad of markers for identifying children at high risk of developing insulin-dependent diabetes mellitus. JAMA 254:1469-1470

14. Riley WJ, Maclaren NK, Krischer J et al. (1990) A prospective study of the development of diabetes in relatives of patients with insulin-dependent diabetes. N Engl J Med 323: 1167-1172

15. Bonifacio E, Bingley PJ, Shattock M et al. (1990) Quantification of islet cell antibodies and prediction of insulin dependent diabetes. Lancet 335: 147-149

16. Chase HP, Voss MA, Butler-Simon N, Hoops S, O'Brien D, Dobersen MJ (1987) Diagnosis of pre-type 1 diabetes. J Pediatr 111: $807-812$

17. Dahlquist G, Blom L, Tuvemo T, Nyström L, Sandström A, Wall S (1989) The Swedish childhood diabetes study - results from a nine year case register and one year case-referent study indicating that type 1 (insulin-dependent) diabetes mellitus is associated with both type 2 (non-insulin-dependent) diabetes mellitus and autoimmune disorders. Diabetologia $32: 2-6$

18. Metcalfe MA, Baum JD (1991) Incidence of insulin dependent diabetes in children aged under 15 years in the British Isles during 1988. Br Med J 302: 443-447

19. Tuomilehto J, Rewers M, Reunanen A et al. (1991) Increasing trend in type 1 (insulin-dependent) diabetes mellitus in childhood in Finland. Diabetologia 34: 282-287

20. Dahlquist $G$, Gustavsson KH, Holmgren G et al. (1982) The incidence of diabetes mellitus in Swedish children 0-14 years of age. Acta Pædiatr Scand 71: 7-14

21. Dahlquist $G$, Blom L, Holmgren $G$ et al. (1985) The epidemiology of diabetes in Swedish children 0-14 years old: a six-year prospective study. Diabetologia 28: 802-808

22. Nyström L, Dahlquist G, Rewers M, Wall S (1990) The Swedish childhood diabetes study: an analysis of the temporal variation in diabetes incidence 1978-1987. Int J Epidemiol 19: 141-146

23. Landin-Olsson M, Karlsson A, Dahiquist $G$, Blom L, Lernmark $\AA$, Sundkvist $\mathrm{G}$ (1989) Islet cell and other organ-specific autoantibodies in all children developing type 1 (insulin-dependent) diabetes mellitus in Sweden during one year and in matched control children. Diabetologia 32: 387-395

24. Madsen OD, Landin-OIsson M, Bille G et al. (1986) A two-colour immunofluorescence test with a monoclonal human proinsulin antibody improves the assay for islet cell antibodies. Diabetologia 29: 115-118

25. Landin-Olsson M, Sundkvist G, Lernmark A (1987) Prolonged incubation in the two-colour immunofluorescence test increases the prevalence and titres of islet cell antibodies in type 1 (insulindependent) diabetes mellitus. Diabetologia 30:327-332

26. Landin-Olsson M (1990) Precision of the islet cell antibody assay depends on the pancreas. J Clin Lab Anal 4: 289-294
27. Palmer JP (1987) Insulin autoantibodies: their role in the pathogenesis of IDDM. Diabetes Metab Rev 3: 1005-1015

28. Baekkeskov S, Nielsen JH, Mamer B, Bilde T, Ludvigsson J, Lernmark $\AA$ (1982) Autoantibodies in newly diagnosed diabetic children immunoprecipitate human pancreatic islet cell proteins. Nature 298: 167-169

29. Baekkeskov S, Warnock G, Christie M, Rajotte RV, Larsen PM, Fey S (1990) Revelation of specificity of $64 \mathrm{~K}$ autoantibodies in IDDM serums by high-resolution 2-D gel electrophoresis. Diabetes 38: 1133-1141

30. Lernmark Å, Freedman ZR, Hofmann C et al. (1978) Islet-cellsurface antibodies in juvenile diabetes mellitus. $N$ Engl J Med $299: 375-380$

31. Van de Winkle M, Smets G, Gepts W, Pipeleers DG (1982) Islet cell surface antibodies. J Clin Invest 70: 41-49

32. Dobersen MJ, Scharff JE, Ginsberg-Fellner F, Notkins AL (1980) Cytotoxic autoantibodies to beta-cells in the serum of patients with insulin-dependent diabetes mellitus. N Engl J Med 303: 1493-1498

33. Gorsuch AN, Spencer KM, Lister J et al. (1981) Evidence for a long prediabetic period in type 1 (insulin-dependent) diabetes mellitus. Lancet II: 1363-1365

34. Arslanian SA Becker DJ, Rabin B et al. (1985) Correlates of insulin antibodies in newly diagnosed children with insulin-dependent diabetes before insulin therapy. Diabetes 34:926-930

35. Sochett E, Daneman D (1989) Relationship of insulin autoantibodies to presentation and early course of IDDM in children. Diabetes Care 12: 517-523

36. Srikanta S, Ricker AT, McCulloch DK, Soeldner JS, Eisenbarth GS, Palmer JP (1986) Autoimmunity to insulin, beta cell dysfunction, and development of insulin-dependent diabetes melli-. tus. Diabetes 35:139-142

37. Karjalainen J (1990) Islet cell antibodies as predictive markers for IDDM in children with high background incidence of disease. Diabetes 39: 1144-1150

38. Levy-Marchal C, Bridel MP, Ticket J, Czernichow P (1991) Prevalence of islet cell (ICA) and insulin (IAA) autoantibodies in normal French children. Diabetes 40 [Supp. 1]:275 Abstract

39. Dahlquist G (1991) Epidemiological and ethical considerations on trials with immunotherapy in pre-type 1 (insulin-dependent) diabetes mellitus. Diabetologia 34: 536 (Letter)

Received: 13 April 1992

and in revised form: 10 July 1992

Dr. A. Lernmark

Department of Medicine

University of Washington, RG-20

Seattle, WA 98195

USA 